\title{
Violencia y Trabajadores del Petróleo
}

\author{
Violence and the Oil Workers.
}

\section{Resumen:}

El presente artículo presenta resultados de investigación que pretende evidenciar la dramática situación de una región de Colombia que se ha convertido en uno de los escenarios de guerra, por parte de los grupos paramilitares, contra dirigentes, activistas sociales, militantes o disidentes políticos. Durante los últimos 25 años se han registrado alrededor de una centena de asesinatos de trabajadores petroleros vinculados a la Unión Sindical Obrera (USO) y para entender este fenómeno es necesario precisar el contexto histórico y señalar cómo surgió y se expandió el paramilitarismo por el Magdalena Medio desde comienzos de la década de 1980, financiados y auspiciados por distintos sectores de la sociedad colombiana. Es necesario recalcar que el ataque contra los sindicalistas es un crimen de "lesa humanidad", tanto en Colombia como en el resto del mundo.

\section{Palabras clave:}

asesinatos de sindicalistas, derechos humanos, paramilitarismo, Trabajadores petroleros, conflicto armado.

\section{Abstract:}

This article shows the research results which aims at proving the dramatic situation of a region in Colombia which has become one of the war scenarios, on the part of paramilitary groups, against leaders, social activists or political militants or dissidents. For the last 25 years, there have been a hundred killings or so of union workers linked with Worker's Union (USO) and in order to understand this phenomenon, it is necessary to define the historic context and point out how Paramilitarism appeared and expanded throughout Magdalena Medio at the beginning of the 1980's, which was financed and sponsored by different sectors of the Colombian society. It is necessary to highlight that the attack against union workers is a crime against humanity, both in Colombia and the rest of the world.

\section{Keywords:}

Killing of Union Workers; Human Rights; Paramilitarism, Oil Workers and Armed Conflict.

\footnotetext{
'Docente investigador Universidad Pedagógica de Bogotá. pen_critico@yahoo.es
} 


\section{Introducción}

La Unión Sindical Obrera (USO) es una organización que agrupa a los trabajadores petroleros, fundada en 1923, ha realizado importantes luchas por la defensa y nacionalización de los hidrocarburos en Colombia. Junto con trabajadores de otros sectores (bananeros, palmeros, carboneros), los petroleros, agrupados en la USO, han sido víctimas de una sistemática campaña de persecución y asesinatos durante los últimos veinte años. La sede principal de la USO se encuentra en la ciudad de Barrancabermeja, una población que se encuentra en la primera zona petrolera del país, situada en la región del Magdalena Medio. Esta región se ha convertido en uno de los escenarios de guerra, por parte del Estado y los paramilitares, contra dirigentes, activistas sociales, militantes o disidentes políticos. En consecuencia, durante los últimos 25 años, alrededor de una centena de trabajadores petroleros vinculados a la USO han sido asesinados, sin mencionar a quienes han sido víctimas de atentados, torturas, amenazas, allanamientos y otras formas de hostigamiento. Antes de entrar a considerar el asesinato de sindicalistas y trabajadores de la USO, es necesario precisar el contexto histórico y señalar cómo surgió y se expandió el paramilitarismo por el Magdalena Medio, desde comienzos de la década de 1980, organizando una red de asesinos, financiados y auspiciados por distintos sectores del Estado por las clases dominantes, con el fin de liquidar las diversas expresiones de protesta de los sectores populares de la región, incluyendo, desde luego, a los trabajadores sindicalizados. Este ataque contra los sindicalistas colombianos es un crimen de lesa humanidad, que por desgracia es prácticamente desconocido, tanto en Colombia como en el resto del mundo.

\subsection{Nacimiento de los grupos paramilitares en el Magdalena Medio}

Los grupos paramilitares surgieron en el Magdalena Medio a finales de 1981 y comienzos de 1982, un momento donde se empezó a hablar de paz con diversas organizaciones insurgentes. En diciembre de 1981 en la ciudad de Cali, fueron arrojados panfletos desde un avión durante la celebración de un partido de fútbol, firmados por la sigla MAS (Muerte a Secuestradores), que en los años siguientes adquirió un tinte siniestro. Esta era una organización criminal financiada por 223 narcotraficantes, para combatir al M-19, que había raptado a una de las hijas del clan Ochoa, del cartel de Medellín. Inmediatamente, el esquema del MAS -grupos de sicarios y asesinos financiados por barones de la droga- fue replicado en el Magdalena Medio, específicamente en Puerto Boyacá. En esta localidad petrolera, bajo la dirección de miembros del Batallón de Infantería Bárbula No. 3 y el Alcalde militar de aquella localidad, se acogió e impulsó el MAS, que fue respaldado y financiado por ganaderos, comerciantes, empresarios, terratenientes, militantes de los partidos liberal y conservador, representantes de la Texas Petroleum Company, integrantes de la Defensa Civil, agentes del DAS, el F-2 y "pájaros" que habían actuado a favor de la Texas en los conflictos laborales² (Zamora, Gloria; 1983: 37-39). 
Su objetivo era limpiar la región de "subversivos", calificación genérica en la que cabían todos los que pensaran y actuaran en forma distinta a lo establecido, para lo cual organizaron un ejército propio, en el que participaban civiles y personal activo del Ejército colombiano ${ }^{3}$ (Medina y Tellez; 1994:88-89). Inmediatamente empezó a operar el MAS, atacando a los que fueron declarados como sus enemigos, entre los cuales se encontraban miembros del partido liberal, dirigentes sindicales, campesinos y trabajadores. Adicionalmente, el MAS creó la Asociación Campesina de Agricultores y Ganaderos del Magdalena Medio (ACDEGAM), que se encargó de identificar a los que consideraba como voceros del comunismo y procedía, en alianza con el ejército, a amenazarlos y asesinarlos ${ }^{4}$ (Medina Carlos; 1990:219). Esto se daba en medio de las negociaciones de paz entre el Estado colombiano y varios grupos insurgentes, como resultado de las cuales fue creada la Unión Patriota y sectores de la guerrilla se legalizaron. Muchos de ellos y miles de militantes de la UP fueron asesinados en los años siguientes.

En el Magdalena Medio, la ACDEGAM se fortaleció con el apoyo de poderosos narcotraficantes que habían comprado tierras y propiedades en la región. Éstos financiaron a nuevos grupos paramilitares, ahora contando con el entrenamiento de mercenarios internacionales, procedentes de Israel y Gran Bretaña ( Cambio; 1993:13) La alianza entre terratenientes y paramilitares con narcotraficantes facilitó la expansión del paramilitarismo, porque le inyectó gran cantidad de dinero para comprar armamento, medios de transporte y equipos de comunicación. Esto multiplicó la violencia contra quienes fueron declarados enemigos del establecimiento, entendiendo por tales a aquellos que planteaban y pretendían la construcción de una sociedad democrática y más igualitaria. Por ello, "junto con el surgimiento de los grupos paramilitares se desarrolla otra fenómeno inquietante: la violencia se incrementó en las principales ciudades y en las regiones con agitación social y conflicto político"6. (Romero Romero;2003:26). En estas condiciones, el móvil central del paramilitarismo no era el narcotráfico, sino que éste era una fuente de financiación, que formaba parte de una estrategia integral de las clases dominantes de este país, cuya finalidad era "la articulación política al modelo de seguridad neoliberal cuya implantación se busca" ${ }^{\prime 7}$.

A mediados de la década de 1980, el tenebroso MAS se había extendido a ocho Departamentos del país, Antioquia, Boyacá, Caquetá, Córdoba, Cundinamarca, Meta, Putumayo, y Santander, en donde grupos organizados de paramilitares, con armas y pertrechos del Ejército colombiano y contando con la accesoria de secciones regionales de inteligencia del Ejército, dirigidos por el Batallón de Inteligencia Charry Solano, desarrollaban actividades criminales contra activistas políticos de izquierda, dirigentes cívicos y populares y sindicalistas ${ }^{8}$. El resultado sangriento alcanzó su punto máximo, en esta primera época, en 1988, cuando se efectuaron más de 100 masacres. Como lo relató en 1989 el sicario Alberto Molina Urrea, quien en una declaración libre a la Procuraduría Delegada para la Policía Nacional, señalaba: "(...) dí de baja a un sindicalista de Ecopetrol, no recuerdo el nombre, sé que le decían Ramón (...) Este último caso lo consumí en Barrancabermeja en un restaurante (...), eran las ocho de la noche. En este restaurante él estaba comiendo, esto sucedió el año pasado (1988) en octubre o finales de septiembre (... $)^{\prime \prime}$. 
A finales de la década de 1980 las acciones criminales de los paras empezaron a ser complementadas por actuaciones similares del Ejército, cuyos "operativos militares que empezaban siempre con bombardeos, continuaban con incursiones terrestres a las veredas y los caseríos, muchas veces acompañadas de asesinatos, quemas de casas y destrucción de muchas cosas de los campesinos y por eso la gente huía". Sin embargo, todavía el paramilitarismo no había entrado plenamente, porque "la gente sabía que esos operativos tenían su límite"10. Esta posibilidad de retorno cambió poco después, porque las acciones puntuales del ejército o de grupos paramilitares que golpeaban y se retiraban dieron paso a incursiones que buscaban establecerse de manera definitiva en el territorio. Esto derivó en una contrainsurgencia permanente, a través de los paramilitares que habían surgido en el Territorio Vásquez de Boyacá.

\subsection{Avance del paramilitarismo en el Magdalena Medio y Barrancabermeja}

En el Magdalena Medio, desde hace varias décadas se ha puesto en marcha un modelo que ha recorrido varias fases. Una primera, en el decenio de 1980, inició la "liberación" de zonas que se consideraban ocupadas por el movimiento insurgente y sus bases de apoyo. Para ello se reconcentró la tierra, se impulsó la construcción de infraestructura de comunicaciones, se consolidó la economía ganadera y se fortaleció el autoritarismo y la persecución contra los que eran declarados como voceros de la subversión. La segunda fase se inició en la década de 1990, con el sofisma de llevar riqueza a la región "liberada" mediante la entrega subsidiada de tierras, la generación de empleo, el crecimiento de las ciudades mediante la incorporación de población traída de otras partes, como base social del proyecto paramilitar, el suministro de energía, asistencia técnica y prestamos para la producción. En esta fase, participaron diversos organismos del Estado para facilitar la incorporación de esa población importada para servir a los patrones y a las autodefensas paramilitares. La tercera fase ha sido de consolidación y legitimación del modelo paramilitar: "Una vez se consolide el modelo de 'seguridad' en las regiones 'liberadas', sin subversivos ni bases comunitarias de apoyo, los paramilitares consideran que dejaran de ser 'una rueda suelta para el Estado'". En este momento se daba por sentado la consolidación de la seguridad, como requisito para garantizar la penetración del capitalismo transnacional y nacional y de un estado modernizante, pero todo ello sólo era posible con la participación del sector privado, los gremios, las ONG's y las comunidades "organizadas" a la manera neoliberal, es decir, funcionando bajo la égida del capital privado y sin derecho a protestar, simplemente siendo obedientes y sumisos ${ }^{11}$ ( Sarmiento Anzola; 1996).

En Barrancabermeja este proceso se ha desarrollado en una forma similar a la descrita en los párrafos anteriores, desde las primeras escaramuzas y ataques selectivos contra dirigentes sociales y sindicales a mediados de la década de 1980, siguiendo con la conquista de las zonas agrarias circundantes a la ciudad en la década de 1990, continuando con masacres, como la del 16 de mayo de 1998, hasta la llegada de los paramilitares al puerto, a finales del 2000. 


\subsection{La importancia estratégica del magdalena medio en la guerra mundial por los recursos}

El paramilitarismo en la sociedad colombiana no es algo marginal, extraño a nuestro país, sino que es un fenómeno estructural que "surge y se desarrolla en la dinámica de los conflictos de clase". En este sentido, "sus fines y objetivos no se diferencian en forma sustancial de los de las clases dominantes, al igual que ellas, es anticomunista, antisubversivo, defiende la estabilidad del régimen y la preservación de los valores políticos, culturales y morales que lo sostienen". Por este carácter de clase, los grupos paramilitares "no representan, en condiciones normales, mayor problema para los sectores dominantes. De sus operaciones de exterminio se benefician los terratenientes, la burguesía, los partidos tradicionales, la iglesia y las fuerzas militares, y se ven seriamente afectadas las organizaciones sindicales, campesinas, populares y los movimientos políticos de izquierda" ${ }^{\prime 2}$.

El paramilitarismo, como instrumento de las clases dominantes y del Estado en las zonas petroleras, opera en concordancia con sus intereses estratégicos, de mantener el control de los recursos y las rentas que de allí se derivan. En estas circunstancias, en Barrancabermeja en particular y en todas las zonas petroleras, en general, la violencia paramilitar no puede explicarse simplemente como una lucha por el control del territorio sino como un mecanismo que hace parte de la estrategia encaminada a apropiarse de recursos esenciales para el capitalismo, nacional y transnacional. Una mirada de conjunto a las guerras que hoy se libran en diversos lugares del mundo, indica la relación entre conflictos y reservas de recursos minerales o energéticos (como petróleo, gas, coltán, diamantes, oro...), como sucede en República Democrática del Congo, algunas de las antiguas repúblicas soviéticas e Irak. Colombia no es la excepción a esa guerra mundial por los recursos, más bien es un eslabón importante en América Latina ${ }^{13}$.

En el caso colombiano se evidencia una sincronía casi perfecta entre las zonas petroleras y la presencia de grupos paramilitares en las últimas décadas. Eso se observa en todo el Magdalena Medio (en las dos orillas del río a donde hay petróleo), en Sabana de Torres y también en El Catatumbo. En la lógica de apropiarse de los recursos, los habitantes locales -sobre todo los de las áreas rurales- son vistos como un estorbo para la apropiación plena de los recursos por parte de empresarios nacionales y/o de compañías transnacionales, como consecuencia de lo cual se ha implementado el destierro violento de la gente, para que la tierra quede libre, con sus recursos minerales y energéticos, y pueda ser apropiada sin obstáculos por los capitalistas. En este sentido, los paramilitares cumplen el papel de limpiar la tierra, para garantizar las inversiones y proporcionar seguridad al capital extranjero.

Así las cosas, la violencia paramilitar en las regiones petroleras no es resultado de la pretendida debilidad del Estado -en la que se suele exaltar su incapacidad militar para imponer el orden y proporcionar seguridad a las actividades económicas y empresariales-, antes por el contrario, es una expresión de su fuerte presencia como ente represivo. $O$, en otros términos, como al 
Estado colombiano y a las clases dominantes de este país no les interesa la gente, sino garantizar la explotación de los recursos, no hay ningún tipo de abandono, sino, por el contrario, una amplia participación del Estado, empezando por sus fuerzas represivas, para garantizar la explotación de esos recursos por empresas multinacionales. Por ello, los paramilitares limpian el terreno de indeseables y luego se atrincheran para defender las tierras y los recursos que allí se encuentran ${ }^{14}$ (Gearoid O; 2007). No es accidental que, en pos de los recursos petroleros, minerales y forestales en este país haya sido concebido el Plan Colombia por parte de los Estados Unidos, con la obvia participación y complicidad de las clases dominantes criollas y del Estado. En este Plan estratégico del imperialismo estadounidense queda claro que las inversiones militares tienen la finalidad de garantizar el flujo constante de recursos naturales de la zona andina hacia el territorio de los Estados Unidos.

En las zonas petroleras, como en el Magdalena Medio y en El Catatumbo, la violencia estatal y para-estatal se encuentra asociada a tres procesos complementarios: una acumulación de capital alrededor de la explotación de recursos naturales de tipo minero y energético, esenciales para los sectores dominantes del capital local y transnacional; la presencia armada del Estado en las regiones, no con el ánimo de mejorar las condiciones de vida de la población sino con el fin de proteger los recursos naturales y las inversiones de capital allí existentes; el ataque a los proyectos democráticos en los que participen sectores populares, cuya acción cuestione las formas convencionales de poder y dominación de terratenientes y empresarios privados y que a la larga podría repercutir en un reparto más igualitario de la renta petrolera ${ }^{15}$ ( Nunca mas; 2008).

Es apenas obvio que con la diversidad de recursos mineros, energéticos, forestales y agrícolas con los que cuentan estas regiones sean un bocado apetecido por las empresas multinacionales y los países imperialistas y, por ende, no es de extrañar la presencia de los paramilitares. Estos ejércitos privados son mercenarios al servicio del capital, local e imperialista, porque a los lugares a donde llegan, vienen acompañados de la "inversión extranjera", tan exaltada como vehículo de desarrollo del modelo neoliberal en las últimas décadas.

Algunos elementos adicionales permiten sopesar la importancia que el petróleo colombiano ha ido adquiriendo, a pesar de que nuestro país no es un país petrolero, a medida que se agotan las reservas mundiales de crudo. Por ejemplo, durante el gobierno de Andrés Pastrana (19982002) aumentó el peso de las multinacionales del petróleo, ya que éstas obtuvieron 70 concesiones de explotación por el Ministerio de Minas, se les disminuyeron los impuestos del $16 \%$ al $5 \%$ y se redujo la cuota de participación de Ecopetrol del 50 al $25 \%{ }^{16}$. De la misma forma, Defense Systems Colombia (DSC), una entidad mercenaria de los Estados Unidos, se encuentra en Colombia desde 1991 para proteger los oleoductos de la British Petroleum, y, en diversas ocasiones, fue acusada por la USO y otras organizaciones laborales de haber fichado a los sindicalistas y entregado los expedientes al ejército y a la policía, que a su vez suministraban la información a las AUC, las cuales procedían a ejecutar, torturar o desaparecer a los señalados ${ }^{17}$. 
En esta misma lógica antinacional de los gobiernos de turno y de las clases dominantes criollas, durante los últimos años, Ecopetrol ha venido desmantelando la estructura productiva en El Catatumbo, incluyendo el cierre de la refinería de Tibú, argumentando que allí el petróleo prácticamente se ha agotado. En esa dirección, se ha pretendido entregar los yacimientos, supuestamente agotados, en concesión para la exploración y explotación al capital privado. Precisamente, el "control paramilitar de algunas zonas y centros urbanos de la región ha permitido, desde fines de los noventa, que empresas extranjeras adelanten sus trabajos de sísmica con el fin de evaluar el verdadero potencial de los yacimientos. Los centenares de muertos y miles de desplazados que ha provocado la presencia paramilitar, coinciden con el asentamiento de los proyectos empresariales extranjeros" ${ }^{18}$ ( Nunca mas ;2008)

Lo que sucedió en Tibú indica la relación que existe entre la apropiación de recursos estratégicos, los intereses capitalistas (locales y transnacionales) y la presencia de los paramilitares. Cuando estos últimos se tomaron Tibú en 1999, lo primero que hicieron fue asegurar las instalaciones petroleras, ya que su objetivo era "desplazar a la insurgencia de las zonas de influencia del oleoducto y una vez logrado, establecieron un control para asegurar que las guerrillas no volvieran". Esto se entiende en el contexto de brindarle seguridad al oleoducto Caño Limón - Coveñas, "que pasa por el Municipio de Tibú, antes de salir en la dirección del César, pasando por el Catatumbo Medio". Tras la aparente desmovilización de los paramilitares, el Ejército "ha tomado el relevo en la protección de esas instalaciones". Por eso, "se crearon nuevos batallones y una brigada móvil con ese fin, aunque públicamente no se lo explicó así. No obstante, el Teniente Coronel Castillo en una presentación en la ciudad de Cúcuta en el año 2005, afirmó que la desmovilización del Bloque Catatumbo "generó 'sensación de inseguridad a la población' (léase empresas petroleras) y que ellos aumentaron el número de efectivos en la zona por el aumento de las actividades mineras y petroleras". En pocas palabras, "las empresas tienen la seguridad que quieren, antes con los paramilitares y ahora con el Ejército"19 ( Gearoid O; 2007 ).

Para las compañías transnacionales la explotación del petróleo en El Catatumbo volvió a ser rentable, gracias a los paramilitares porque si estos "actuaron bajo las órdenes de una u otra petrolera es intrascendente, el asunto es que sin los paramilitares no habría exploración" ${ }^{20}$. Y esto se confirma con el incremento de los contratos de exploración y producción de hidrocarburos en Norte de Santander, como no se había presentado antes, lo cual a primera vista es sorprendente porque desde la década de 1960 se había anunciado por parte de la Colpet que el petróleo de El Catatumbo se había agotado definitivamente.

\section{Metodología:}

Para identificar los enlaces de las dinámicas de violencia dirigida contra el sector sindical, se desarrollaron cuatro niveles metodológicos: el análisis de bibliografía especializada que permitirá identificar referentes temáticos que han comprometido el incremento de la violencia antisindical en esta zona del país y los actores locales en la configuración del fenómeno; el 
segundo nivel metodológico está relacionado con el análisis de los datos estadísticos de fuentes institucionales que dan cuenta de la violencia antisindical, en específico de los asesinatos, para identificar vínculos con diversos sectores de la sociedad, actores amados e institucionales; el cuarto nivel metodológico está relacionado con el rastreo de prensa local, regional y nacional que permitieron obtener y sistematizar información sobre límites y dinámicas de los poderes locales y nacionales que intervienen en el desarrollo de esta realidad.

\section{Resultados}

\subsection{El asesinato de trabajadores y dirigentes sindicales de la USO}

Uno de los aspectos centrales de las transformaciones del mundo del trabajo en todo el planeta durante los últimos quince años es la flexibilización laboral, como parte de una política encaminada a desvalorizar al máximo la fuerza de trabajo y a incrementar las ganancias de los capitalistas. Esta política ha significado una modificación (no desaparición) del papel del Estado en general y en particular en lo relacionado con la regulación entre capital y trabajo, dando paso a la constitución del "estado competitivo", favorable a la desregulación plena del mercado laboral, para que los trabajadores puedan ser libremente explotados, por los capitalistas nacionales y por los inversores. Esto ha modificado sustancialmente las condiciones de los trabajadores y ocasionado la pérdida de importantes conquistas históricas, tales como desaparición de la estabilidad laboral, la prohibición de organizar sindicatos, la prolongación de la jornada de trabajo, el desempleo, la disminución de los salarios reales y el incremento en la explotación de hombres, mujeres y niños. Estos resultados de la flexibilización laboral sólo han sido posibles mediante la "violencia legitima" de los Estados contra los trabajadores y sus formas organizativas, a nombre de la competitividad y la modernización en tiempos de globalización.

Este proceso se ha desarrollado tanto en Colombia, como en el resto de los países de América Latina, pero en nuestro país hay un elemento completamente distinto, único en su género, puesto que la violencia directa ejercida contra los trabajadores y sus organizaciones sindicales ha sido un componente indispensable de la flexibilización laboral. En este caso, el exterminio físico de los sindicalistas ha sido un proyecto sistemático llevado a la práctica durante los últimos 20 años, que ha generado una situación única y prototípica, sin parangón en ningún otro lugar del orbe, por las dimensiones alcanzadas y por su permanente impunidad. Entre 1987 y 2008 han sido asesinados cerca de 3000 líderes sindicales en todo el país, un hecho dramático relacionado con la flexibilización laboral que se ha aplicado desde hace dos décadas, o, más exactamente, esa flexibilización viene acompañada de la violencia institucional y parainstitucional contra los trabajadores que han osado resistir a la arremetida impulsada por el capitalismo nacional e internacional (porque empresas como la Coca Cola y otras similares están detrás del exterminio de trabajadores y sindicatos).

El despliegue militar contra los trabajadores en todo el país ha sido uno de los factores de consolidación del modelo neoliberal, como puede apreciarse en Antioquia con los bananeros, 
en el Cesar con los de la palma africana, en la Guajira con los carboneros y, por supuesto, con los petroleros en el Magdalena Medio y en El Catatumbo. La violencia paramilitar pretende destruir las organizaciones de los obreros, impedir su movilización, negar las peticiones y reclamos e imponer la flexibilización, con medidas para mejorar la productividad fusionando cargos y labores, reduciendo salarios, eliminando el empleo estable e imponiendo el trabajo temporal mediante la creación de cooperativas de trabajo asociado y la generalización de contratistas $^{21}$. En este sentido:

"la persecución, hostigamiento y crímenes de lesa humanidad contra los sindicatos de algunas empresas claves en el modelo económico se han impuesto para lograr condiciones favorables y obtener ventajas dentro de la política de apertura económica, siendo complementados integralmente por la acción paramilitar y militar, de donde provienen procedimientos "legales" e ilegales, amenazas, presiones y crímenes de lesa humanidad que resultaron fundamentales para imponer la flexibilización laboral y cumplir las metas institucionales trazadas por las empresas en el marco de la liberalización económica. La persecución contra los sindicatos (...) ha dejado algunas organizaciones gremiales destruidas y gran cantidad de mano de obra sindicalizada desplazada"22 (Nunca mas; 2008 ).

Los trabajadores sindicalizados han sido sometidos a diversas formas de persecución, que van desde el allanamiento de las sedes sindicales hasta la desaparición forzosa, pasando por las torturas, el encarcelamiento, el señalamiento público como subversivo y enemigo del país, el extrañamiento de sus lugares de origen, el exilio forzoso, la expulsión del trabajo y la criminalización de la actividad gremial y política.

Hoy por hoy, Colombia es el lugar del mundo más peligroso para ejercer cualquier actividad reivindicativa, en el terreno que sea: como defensor de derechos humanos, como activista estudiantil, como líder campesino, como comunicador popular y, por supuesto, como sindicalista. Las cifras muestran año a año, con una terrible contundencia, que este país es el primero en asesinato de sindicalistas en todo el planeta como se evidencia en el siguiente cuadro: 


\section{CUADRO No. 1 \\ HOMICIDIOS CONTRA SINDICALISTAS EN COLOMBIA Y EN EL MUNDO (1999-2005)}

\begin{tabular}{|c|c|c|c|}
\hline AÑO & $\begin{array}{c}\text { Homicidios en todo el } \\
\text { mundo }\end{array}$ & homicidios en Colombia & $\begin{array}{c}\text { Porcentaje de homicidios en } \\
\text { Colombia }\end{array}$ \\
\hline 1999 & 140 & 80 & 57 \\
\hline 2000 & 209 & 137 & 66 \\
\hline 2001 & 223 & 197 & 88 \\
\hline 2002 & 213 & 186 & 85 \\
\hline 2003 & 129 & 94 & 73 \\
\hline 2004 & 145 & 96 & 66 \\
\hline 2005 & 115 & 70 & 61 \\
\hline
\end{tabular}

FUENTE: Guillermo Correa Montoya, 2515 o esa siniestra facilidad para olvidar. 21 años de asesinatos de sindicalistas en Colombia, Cuaderno de Derechos Humanos No. 19, Escuela Nacional Sindical, Medellín, julio de 2007, p. 18.

El proyecto capitalista actual en términos laborales impulsa la flexibilización utilizando todas las formas de lucha (legal, judicial, mediática y armada). Eso lo tienen claro los grupos paramilitares y sus patrocinadores, tal y como ha sucedido en el Magdalena Medio, donde a raíz del Plan Colombia se han impulsado las cooperativas asociadas de trabajadores y ONG's con nombres que imitan a las defensoras de derechos humanos ${ }^{23}$.

El asesinato de dirigentes sindicales en Colombia es resultado de una campaña sistemática, financiada por diversos sectores de las clases dominantes, que han contratado a sicarios y paramilitares, para "limpiar" los lugares de trabajo de los incómodos obstáculos que impiden el funcionamiento armonioso del libre mercado, empezando por la eliminación de los sindicalistas. Al respecto, el jefe paramilitar Carlos Castaño afirmó sin aspavientos que los atentados contra los dirigentes sindicales no eran ciegos, pues siempre había una razón: "Los sindicalistas, por ejemplo, ile impiden trabajar a la gente! Por eso los matamos". Por ello, el periodista Fernando Garavito preguntó en agosto de 2002: ¿ "Quiere usted morir en el curso de los próximos días?" y no dudo en responder que "la formula es simple: afíliese a un sindicato. En menos que canta un gallo las fuerzas oscuras que pululan en este país y que son simplemente eso, fuerzas oscuras, lo darán de baja en cualquier esquina" ${ }^{24}$.

Aunque el asesinato de sindicalistas se inscribe en el ámbito del conflicto armado interno que se vive en el país, la gran mayoría de las violaciones a los derechos humanos de que son victimas los sindicalistas se encuentra vinculada con "conflictos laborales (paros, huelgas, negociaciones colectivas y creación de sindicatos)". Puede decirse con perfecta certeza que la violencia contra los sindicalistas es "una acción deliberada, estratégica y sistemática, que obedece a un interés específico que busca anular las acciones sindicales de reivindicación y defensa de los derechos laborales". No por casualidad, "las violaciones se han realizado en momentos marcados por el 
aumento de las reivindicaciones laborales y no como consecuencia del conflicto armado; de ahí que los y las sindicalistas no aparecen como victimas casuales o colaterales del conflicto armado".

Existe una "cultura antisindical", que se ha extendido desde las altas esferas de las clases dominantes hasta sectores comunes y corrientes de la población, para la cual los trabajadores sindicalizados son una amenaza interna para la estabilidad del país, una especie de "guerrilleros desarmados" o subversivos de civil. De ahí, la impunidad y la complicidad de amplios sectores de la población con los crímenes de los sindicalistas, cuya principal responsabilidad corre por cuenta del Estado al criminalizar la lucha obrera y popular. El asunto es tan evidente que un periódico oficialista como El Tiempo, ha reconocido que el Estado colombiano "dialoga con más facilidad con los grupos armados que con las organizaciones legitimas del trabajo y que tiende a criminalizar la protesta social" ${ }^{26}$.

Durante los últimos treinta años desde el Estado y contando con la aquiescencia o participación de las clases dominantes se ha llevado a cabo una campaña de persecución contra la USO como organización sindical, contra sus directivos y contra sus afiliados. Ya desde 1978 y 1979 , en Barranca se sintió con particular fuerza la aplicación del funesto Estatuto de Seguridad, siendo perseguidos trabajadores afiliados a la USO por parte de los organismos militares, acantonados en esta localidad. En efecto, sectores de la tropa adscrita al Batallón Nueva Granada detuvieron arbitrariamente, torturaron y acusaron como subversivos a miembros de la USO. En enero de 1978 se realizó un paro en la Planta de Balance de Ecopetrol, que inmediatamente fue militarizada por el ejército, y ese mismo año fue detenido, por miembros del Batallón Nueva Granada, el trabajador Ramón Serrano Rincón, quien luego fue desaparecido ${ }^{27}$ (Nunca mas;2008).

En los primeros años de la década de 1980, el Ejército fue el responsable de allanamientos, detenciones arbitrarias, torturas y sindicaciones abusivas contra miembros de la USO. Se definían dos mecanismos básicos: el primero, al cual recurrieron los directivos de Ecopetrol y los mandos militares, consistía en señalar a los trabajadores sindicalizados de pertenecer a organizaciones insurgentes catalogándolos de terroristas; el segundo, era el ataque directo mediante acciones encubiertas dando paso a la guerra sucia, en la cual se recurría a las amenazas con panfletos y luego al asesinato selectivo de los trabajadores amenazados. Estos crímenes comenzaron a generalizarse después de 1985 y eran realizados por el MAS y otros grupos que se autodenominaban Muerte a Sindicalistas, Comité Cívico de Barrancabermeja o Comité de Gentes Honestas de Barrancabermeja ${ }^{28}$.

En 1988 se presentó la mayor cantidad de asesinatos de sindicalistas de la USO en toda esa década, matanza que coincidió con la participación de la USO en la Coordinadora Popular del Nororiente, la cual impulsó importantes marchas campesinas en ese mismo año tras haberse constituido un año antes. A un mes de las jornadas de protesta, en julio de 1987 fue asesinado el ex directivo de la USO Euclides Garzón por agentes del Estado que se presentaron como paramilitares del MAS. Dos meses después, en septiembre, otros dos trabajadores de Ecopetrol, Aníbal Ramírez Silva y Milton García, fueron retenidos al salir de la empresa y al día siguiente aparecieron muertos en La Lizama ${ }^{29}$. 
Uno de los hechos que más impactó a Barrancabermeja y a la USO fue el asesinato del dirigente popular Manuel Gustavo Chacón el 15 de enero de 1988. Tan pronto cayó herido de muerte en una calle céntrica de Barrancabermeja, se paralizó la ciudad, se cerró el comercio y se guardaron las motos y los carros. La Coordinadora Popular llamó a un paro cívico que se hizo efectivo de manera inmediata y los trabajadores de la USO cesaron actividades varias días y hasta la refinería dejó de funcionar. El cuerpo de Chacón estuvo en cámara ardiente en la sede nacional de la USO, recibiendo homenajes y despedidas de toda la población del puerto, pero al tercer día el Ejército atacó con gases lacrimógenos a la gente que lo acompañaba y la noche de su entierro, que fue multitudinario, fueron asesinadas siete personas por las fuerzas militares $y$ varias más quedaron heridas.

Cuando comenzó la guerra contra la USO, el sindicato decidió que cada vez que se asesinara a un dirigente o activista se iba a parar la producción. Así, cuando mataron a Chacón:

"Nosotros apagamos toda la refinería. Estuvimos durante seis horas apagándola. Sabíamos que era un riesgo porque había cosas que no dominábamos, porque es muy complicado apagar todo el complejo petroquímico y todos no iban a colaborar. Eso fue una acción dura y un paro cívico duro, el presidente de la República puso una avioneta ahí para que la dirección del sindicato se trasladara a Bogotá para hablar con él directamente. El movimiento había logrado su objetivo, se levantó el paro y se firmó un acuerdo. Una anécdota muy importante nos ocurrió al apagar el cuarto de los turbogeneradores, los que producían energía para todo el complejo. Cuando llegamos allí íbamos a apagar todo y un operador afiliado al sindicato nos dijo: "Ustedes son la dirección del sindicato y en este momento son los que mandan, pero yo les aconsejo que mantengan la más mínima carga porque si ustedes lo apagan del todo, de noche esto queda totalmente a oscuras y entra el ejército y se los carga a ustedes o se los lleva y ustedes no tienen armas. Yo creo que el arma de ustedes es mantener la mínima carga y decir que si el ejército entra a desalojar apagaran todo. Porque además no hay más armas. El día que se apague este turbo con las instalaciones eléctricas que hay ahora en la refinería se tardara unos 15 o 20 días en volver a reactivar la refinería". Discutimos y determinamos por mayoría no apagar todo y aceptar el consejo del trabajador ${ }^{\prime \prime 3}$.

Durante los días del paro, la ciudad estuvo virtualmente gobernada por la Coordinadora Popular, siendo infructuosos los llamados de las autoridades civiles y militares para suspender la protesta. Por supuesto, la reacción no se hizo esperar y en los días posteriores al paro, empezaron a arreciar las amenazas contra los dirigentes populares, por los grupos paramilitares de la región, que firmaban con las siglas de MAS, Boinas Rojas, SAO o MASINGER ${ }^{31}$.

\subsection{Arrecia el asesinato de sindicalistas de la USO}

El asesinato de Chacón fue el punto de partida de la campaña de exterminio librada, por fuerzas militares y paramilitares, contra miembros de la USO. Así, pocos días después de la marcha campesina del nororiente, el 26 de mayo de 1988, fue asesinado Hamet Consuegra 
Llorente, Vicepresidente de la Subdirectiva del Centro, a quien se le disparó desde un carro antimotines por un agente del F-2 que era conocido con el alias de "Cúcuta". Semanas más tarde uno de los testigos de ese crimen fue asesinado, su nombre era Luis Antonio Martínez Duarte y se desempeñaba como trabajador del Distrito de Producción de El Centro. Estaba tomando una gaseosa con otro trabajador, Juan Hernández Dueñas, cuando los dos fueron acribillados por agentes del Estado que se movilizaban en una moto ${ }^{32}$ (Nunca mas; 2008 ).

En la década siguiente, el ataque se dirigió también contra trabajadores contratistas y profesionales que no estaban afiliados a la USO. Estos crímenes eran reivindicados por organizaciones que se llamaban a sí mismas Autodefensas del Magdalena Medio, Autodefensas Urbanas de Barrancabermeja, La Gota Negra y Grupo de Exterminio de Barrancabermeja y Yondó. Existe una terrorífica coincidencia entre períodos de pliego de peticiones de los trabajadores y el aumento de amenazas, atentados, asesinatos y desterrados. Tras este panorama se esconde la flexibilización laboral de Ecopetrol, que ya en 1992 suplía la mitad de todas sus actividades mediante la vinculación de contratistas. Al mismo tiempo, el Estado colombiano impulsó la "justicia sin rostro", un eufemismo para facilitar la judicialización de aquellos trabajadores y dirigentes sindicales considerados como un obstáculo para la imposición plena de la flexibilización labora $^{33}$.

Para completar, muchas de las personas asesinadas en Barrancabermeja en los últimos 25 años, desde la emergencia del MAS, tenían vinculaciones directas o indirectas con la USO y los trabajadores petroleros. Algunos habían sido trabajadores y líderes sindicales de la USO expulsados en las grandes huelgas, como fue el caso de Orlando Higuita, miembro del Partido Comunista y dirigente de la Unión Patriótica. Otros eran líderes sociales y políticos que siempre habían tenido contacto con la USO, para coordinar acciones, solicitar solidaridad o simplemente participar en las luchas cívicas y populares que se adelantaron en el puerto durante las décadas de 1980 y 1990. Entre estos deben mencionarse a algunos de los dirigentes de la Unión Patriótica como Leonardo Posada, asesinado en Barranca en 1986. 
Cuadro No. 2

Victimas de la USO a Manos de Grupos Paramilitares

\begin{tabular}{|c|c|c|c|}
\hline AÑO & MUERTOS & HERIDOS & DESAPARECIDOS \\
\hline 1988 & 10 & & \\
\hline 1989 & 2 & 2 & \\
\hline 1990 & 8 & 5 & \\
\hline 1991 & 14 & 11 & \\
\hline 1992 & 17 & 1 & \\
\hline 1993 & 6 & 6 & \\
\hline 1994 & 1 & & \\
\hline 1995 & 4 & 2 & \\
\hline 1996 & 5 & 1 & \\
\hline 1997 & 3 & 3 & \\
\hline 1998 & 2 & 1 & 1 \\
\hline \multicolumn{4}{|l|}{1999} \\
\hline 2000 & 2 & & \\
\hline 2001 & 4 & & 1 \\
\hline 2002 & 1 & & \\
\hline
\end{tabular}

FUENTE: Gearóid Loingsigh, La estrategia integral del paramilitarismo en el Magdalena Medio de Colombia, s.d., Bogotá, 2004, p. 37.

\subsection{La macabra red de inteligencia 07 de la armada, 1991-1993}

La Red de Inteligencia de la Armada Nacional operó en Barrancabermeja entre los años 1991 y 1993 y se calcula que su actuación criminal produjo la muerte de cerca de un centenar de personas. Según el testimonio proporcionado por dos oficiales que hicieron parte de la misma, esta red organizó y realizó varias masacres, entre las cuales se encuentran la de "El Tropezón", "9 de Abril", "El Cerro", "Billares Versalles", "La Rampla", "El Cincuentenario" y "La Shanon" ${ }^{\prime 34}$.

La reorganización de las Redes de Inteligencia contó con la asesoría del Comando Sur de los Estados Unidos. Como resultado surgió la Orden 200-05/91 del Ministerio de Defensa de Colombia en mayo de 1991, "con base en las recomendaciones que hizo la comisión de asesores de las Fuerzas Militares de los Estados Unidos", presentó un plan para combatir mejor lo que ellos denominaban "la escalada terrorista por parte de la subversión armada.." ${ }^{35}$. La

340

AGO.USB Medellin-Colombia V. 9 N N 2 PP. 294-600 Julio-Diciembre 2009 ISSN: 1657-8031 
reorganización de estas redes de inteligencia recayó en el Jefe del Estado Mayor de las Fuerzas Armadas, y se crearon 30 redes en todo el país, tanto rurales como urbanas. A cada una de las redes se le asignó personal y un oficial en actividad "con gran conocimiento del área, del problema existente, facilidad de tomar contacto con personalidades de la zona y para mantener una fachada." Al mismo tiempo, dicho oficial sería asistido por otro "oficial y/o suboficial retirado o en servicio activo y con medios tales como fachada, historia ficticia, vehículo y un sistema de comunicaciones preestablecido;... También puede ser un civil con preparación, influencia y digno de confianza" ${ }^{36}$. A las órdenes de este funcionario debían estar los "agentes de control... civiles o Suboficiales desempleados con cierta experiencia y categoría" ${ }^{37}$.

La red 07, con sede en Barrancabermeja, tenía jurisdicción en el sur de Bolívar, en parte del Departamento del César y en la capital petrolera de Colombia. Operó entre octubre de 1991 y enero de 1993. Siguiendo las instrucciones del Estado colombiano, la red de Barrancabermeja se presentó como una empresa que ofrecía servicios técnicos a la Naviera Colombia, con sedes propias y civiles, ubicadas en lugares céntricos de Barrancabermeja. Esas sedes sólo eran conocidas por los jefes de la red y ciertos agentes de inteligencia, directamente vinculados con la misma. Los sicarios contratados no tenían ningún nexo directo con la Red, con la obvia intención de que éstos no se enteraran de quienes los contrataban para adelantar los atentados, por lo que se recomendaba claramente a los miembros de la red "evitar asistir a las instalaciones militares" y que sus contactos e intercambios fueran secretos y "siempre dirigidos por los Comandantes de Brigada".

Las acciones emprendidas por la Red, planeadas desde la Central de Inteligencia de la Armada Nacional ubicada en Bogotá, tenían como objetivos prioritarios eliminar a líderes sociales y generar miedo y terror en toda la población. Esta red criminal operaba de la siguiente forma:

"A comienzos de 1992, en Barrancabermeja fueron asesinadas por lo menos un centenar de personas en circunstancias similares. La forma de ejecución de los crímenes, las condiciones sociales y personales de las víctimas y la absoluta impunidad que cubrió a los autores hacían presentir que detrás de estas acciones había una poderosa máquina de muerte, con medios logísticos a su disposición, con hombres entrenados para matar, con selección minuciosa y paciente de las víctimas; en fin, un cerebro criminal que lo tenía todo para cumplir sus objetivos de destrucción y caos. La escena se repitió muchas veces. Los disparos fueron certeros, con preferencia a la cabeza. Los sicarios se movilizaban en moto, disparaban contra sus víctimas y huían. Se les protegía la retirada con intempestivos cortes de energía y la casual ausencia total de la fuerza pública. Nunca hubo una captura o un sospechoso. Después de unas semanas de "investigación exhaustiva", el funcionario judicial encargado de indagar sobre cada hecho en particular, ordenaba suspender la instrucción" ${ }^{\prime 38}$. 
Entre los asesinados por la Red de Inteligencia 07 entre 1991 y 1993 se encontraban defensores de derechos humanos, líderes campesinos, dirigentes sindicales, periodistas, militantes y simpatizantes de movimientos políticos y sociales de izquierda. En cuanto a los sindicatos se refiere, "los sicarios a órdenes de la Red de inteligencia tenían en claro que la actividad sindical era un motivo suficiente para matar, tanto así que existía una tarifa por cada miembro de la USO asesinado", puesto que, según el testimonio rendido por Carlos Alberto Vergara, uno de los sicarios de la Red, "cada asesinato oscilaba entre cien o doscientos mil pesos de acuerdo a la víctima, cada miembro de la USO era pagado con doscientos mil pesos, cada guerrillero a cien mil pesos, por eso se hicieron la cantidad de masacres que hoy por hoy están a la vista pública" ${ }^{\prime \prime 2}$.

El asesinato de sindicalistas no fue resultado de coincidencias desafortunadas o del accionar de sicarios sin norte, sino parte de un engranaje criminal encaminado conscientemente a frenar la lucha sindical y reivindicativa en Barrancabermeja, pues no sólo fueron asesinados trabajadores de la USO, aunque éstos fueran el principal objetivo, ya que también perecieron dirigentes sindicales de otros gremios de la ciudad. Como se dice en el expediente por parte del Juzgado Regional de Cúcuta, según revelo Saulo Segura Palacios, uno de los suboficiales que denunció la existencia de la Red, que "la orden impartida por el oficial Quiñónez Cárdenas, quien desde la capital del país dirigía la banda, fue la de eliminar a los directivos de la Unión Sindical Obrera "USO", materializada por lo menos, en los asesinatos de Luis Fernando León Cáceres y Otoniel Ríos".

“Este mandato se extendió a los regentes de otras agrupaciones, así como a otros legítimos contradictores del régimen, conforme se infiere sin remisión a dudas de los homicidios perpetrados en Parmenio Ruiz Suárez, José Domingo Amaya Parra y Jaime Garcés Núñez, directivos de los sindicatos del transporte; de los atentados en los que resultaron víctimas René Alberto Tavera Sosa y Julio Cesar Berrío Villegas, asistente técnico de la Asociación Nacional de Usuarios Campesinos (ANUC) y activista de los derechos humanos, respectivamente; o del deceso consumado en el periodista Ismael Jaimes Cortes" ${ }^{\prime \prime 4}$.

Ahora bien, esta Red utilizaba informantes clandestinos, los cuales reportaban a una futura víctima por simples sospechas, sin tener ningún indicio ni evidencia, como sucedía con dirigentes sindicales y trabajadores de la USO. Así mismo, entre las macabras claves que empleaban para comunicarse entre los miembros de la red y dar la orden de ejecutar a una de las personas escogidas se encontraba la siguiente: "Hay unos motores fundidos, necesito que los reparen, los tengo en tal sitio y daban la dirección, lleven buenos mecánicos y buena herramienta, mecánicos significa sicarios, buenas herramientas significa buen armamento y motores fundidos significa las víctimas" ${ }^{\prime \prime 1}$. 
La responsabilidad directa de la Armada en la organización de la Red 07 se confirmó cuando dos abogados de la Procuraduría General de la Nación encontraron en la sede del Batallón Nueva Granada de Barranca un cuarto con una puerta blindada en donde localizaron un legajador con quince carpetas, en las cuales se encontraban los recibos de pago mensuales destinados a sicarios, informantes, alquileres y salvoconductos a nombre de los contratados ${ }^{42}$.

Para realizar las labores de exterminio se conformó un grupo de informantes y de sicarios, al cual se le pagaba de la siguiente forma, como lo relató un Suboficial activo de la Armada Nacional, y miembro activo de la Red 07: "Se sobrevaloraba el pago de la información. Es decir, si había una buena información legal. Ejm: ubicación de un grupo subversivo en el área de Barranca, se facturaban $\$ 700.000$, pero solamente se le pagaba al informante $\$ 100.000$, los otros $\$ 600.000$ los utilizaban para cancelar el grupo de sicarios ${ }^{\prime \prime 4}$.

Saulo Segura, uno de los sicarios activos de la Red de Inteligencia de la Armada, al darse cuenta de que los asesinatos cometidos no se libraban, como se le decía en las órdenes impartidas, contra guerrilleros sino contra líderes sociales, confesó: "Había logrado establecer que los que me mandaban a 'tumbar' no eran guerrilleros, ni colaboradores de los mismos, ni narcotraficantes, ni traficantes de armas; al contrario eran personas muy queridas en la región porque son de los pocos que están proporcionado trabajo en la zona" ${ }^{\prime \prime 4}$. Por esta declaración, Segura pasó de ser ejecutor a convertirse en objetivo militar de la Red de Inteligencia. Meses después fue víctima de un primer atentado pero sobrevivió y luego fue asesinado en la Cárcel Modelo de Bogotá, a finales de 1995.

\subsection{Justicia sin rostro, pero de clase contra los dirigentes de la USO}

Justicia sin rostro se denominó al andamiaje jurídico que pretendía juzgar en la década de 1990 a los grandes capos del narcotráfico y, dado el riesgo que implicaba para los jueces dictar sentencia en contra de aquéllos, se determinó cubrirlos para protegerlos. Sin embargo, pronto quedó en evidencia que la finalidad de la tal justicia sin rostro era otra: perseguir, criminalizar y sentenciar a los movimientos sociales y a sus líderes, así como a los miembros de partidos políticos de oposición. Los hechos lo demostraron porque mientras los narcos seguían libres y en completa impunidad, los dirigentes sociales eran judicializados y condenados de manera arbitraria, con el objetivo de sembrar terror y desorganizar a las clases dominadas. Según Eduardo Umaña Mendoza, la justicia sin rostro tenía dos elementos característicos: de un lado, "es una estructura jurídica y burocrática de claro tinte inquisitorial por su carácter reservado, secreto y carente de garantías para el incriminado", en razón de lo cual "constituye el límite más aberrante de violación de tratados y convenios internacionales (...) pues se desconoce (...) el debido proceso, el derecho a la defensa, y la presunción de inocencia"; de otro lado, 
"corresponde a una estructura política degradada, cerrada, corrupta y reaccionaria apoyada por servidores públicos del mismo talante como los altos funcionarios de la administración de justicia". Por estos dos aspectos, la justicia sin rostro pretendía "acallar por todos los medios (judiciales y extrajudiciales) cualquier manifestación de descontento social"45 (Umaña Mendoza; 2008 ).

La justicia sin rostro se ensañó particularmente contra dirigentes de la USO, pues durante la década de 1990 fueron llevados a la cárcel y procesados, con falsas pruebas, dirigentes petroleros como Pedro Chaparro, César Carrillo, Fernando Acuña, Álvaro Solano, Fredy Pulecio y otros 14 integrantes de la USO. Eduardo Umaña Mendoza, abogado defensor de estos trabajadores y quien fuera asesinado el 18 de abril de 1998, sintetizaba el sentido de los procesos contra los sindicalistas:

"...esto es una telaraña jurídica y una tenaza política porque, en la medida en que se refutan los cargos y se demuestra la inocencia, surgen nuevos hechos sobre los cuales son acusados los dirigentes de la USO. Ahora, la base son testigos indirectos -reservados o no, sin rostro o con rostro- cuya constante tiene que ver con delincuentes que buscan rebajas de penas (...), o testigos que dependen, o viven y conviven con los organismos de seguridad del Estado -como el DAS, el B2, o la Brigada XX- (...) que, simplemente, se prestan para calumniar, aunados ellos a testigos de la misma brigada XX (...) quienes, en esa telaraña jurídica toman ciertos hechos y ubican a ciertos trabajadores de la USO dentro de estos hechos, pero, como nunca han estado allí: no hay indicios, no hay pruebas, no hay documentos, no hay fotografías, no hay circunstancias concretas, entonces los ubican como determinadotes -lo que anteriormente se asimilaría al autor intelectual- porque ninguno de ellos en ninguno de los casos, está acusado de ser autor material puesto que, claro, eso implicaría unas pruebas, unos documentos y unas circunstancias mucho más concretos" ${ }^{\prime \prime 6}$ (Umaña Mendoza; 2008 ).

Los trabajadores de la USO sometidos a la justicia sin rostro tuvieron soportar un sinnúmero de arbitrariedades y violaciones de los más elementales derechos de defensa. En primer lugar, existía una evidente interferencia del poder ejecutivo en los procesos judiciales, como resultado de lo cual "el gobierno a través de peticiones e informes de inteligencia militar relaciona de manera caprichosa e infundada la actividad legal de defensa de derechos de los trabajadores con delitos como rebelión y terrorismo para estigmatizar a los dirigentes y crearles, de manera antelada, cargos en su contra" ${ }^{\prime 47}$. Para ilustrar recordemos que se consideraron como "antecedentes criminales" del dirigente de la USO Fredy Pulecio que se hubiera desempeñado como "presentador del programa radial "Frente Obrero", emitido por la Voz del Petróleo de esa ciudad" y que allí "criticó al gobierno de turno y responsabilizó a las Fuerzas Militares de los hechos de violencia y desapariciones en la zona" ${ }^{\prime \prime 8}$. 
En segundo lugar, se validaron testimonios irregulares, viciados por su origen y con múltiples contradicciones e incoherencias, para encarcelar y condenar a miembros de la USO. Al respecto es destacable que contra Pedro Chaparro y César Carrillo se usaron testimonios de un individuo que estaba alojado en el Batallón Ricaurte y de otro que recibía remuneración del Ejército para declarar en contra de uno de los acusados. Sin disimulo uno de los testigos reconoció que era informante al servicio del Ejército y cuando le indagaron si recibía dinero por la información que suministraba respondió: "Si señor, yo informo y de acuerdo a los resultados que se obtengan me pagan, pero sobretodo es por capturas últimamente y no me han pagado, por eso tengo ganas de retirarme de esto y no seguir colaborando"49. También se clonaron testigos, es decir, que un mismo testigo, aprovechando su reserva de identidad, declaró en dos o tres oportunidades haciéndose pasar por personas diferentes, para dar la apariencia de que existían coincidencias entre varios individuos distintos sobre una misma acusación en contra de los dirigentes de la USO.

En tercer lugar, las actuaciones de altos funcionarios judiciales eran verdaderos exabruptos jurídicos guiados por motivos ideológicos y no basados en el derecho. En el proceso contra el dirigente Pedro Chaparro, el juez, ante la falta de evidencias consistentes se vio obligado a decretar la libertad del sindicado, pero un Tribunal de altos funcionarios de manera discrecional decidió revocar la decisión absolutoria y dictar condena.

Y, en cuarto lugar, "indebido trato a la defensa y condena a muerte al abogado defensor". Este punto podría considerarse como simple especulación, si no estuviera rubricado por la contundencia fáctica que la persona que lo dijo, el abogado Eduardo Umaña Mendoza, fue asesinado pocas semanas después de haberlo denunciado. Este eminente jurista, defensor de derechos humanos y luchador social, había declarado el 18 de febrero de 1998:

"(...) hace aproximadamente quince días recibí sendas llamadas telefónicas, ambas en las horas de la mañana, por parte de una voz masculina, quién manifestó en una y otra ocasión la preocupación por la inminencia de mi asesinato por parte de fiscales regionales, miembros del CTI, orgánicos del B2 y altos funcionarios de la seguridad interna de Ecopetrol. (...) Que los responsables de la planeación y asesinato tienen que ver de manera directa con las investigaciones que se han hecho por parte de la Fiscalia, en el caso del dirigente sindical de la Uso, César Carrillo Amaya. De la misma manera expresó que el motivo de mi asesinato tendría que ver con las averiguaciones y denuncias que he hecho en el proceso contra el dirigente sindical arriba mencionado, a quien defiendo en la actualidad. Decía que yo era un peligro para la investigación en la cual se buscaba condenar a Cesar Carrillo, ya que estaba descubriendo el "montaje" que habían hecho funcionarios de la Fiscalía y el CTI" 
El 28 de abril de ese mismo año se cumplió la amenaza al pie de la letra, cuando Eduardo Umaña Mendoza fue asesinado en su apartamento de Bogotá. De esta manera, no sólo se realizaban atentados y asesinatos de trabajadores petroleros y de dirigentes sindicales de la USO y se procedía a adelantarles procesos judiciales y condenarlos por parte de la justicia sin rostro, sino que se había dado un paso más hacia la impunidad total, con el asesinato de los abogados defensores de la organización sindical.

\subsection{El objetivo esencial del asesinato de sindicalistas de la USO}

Es necesario extraer algunas conclusiones que ayuden a entender el verdadero sentido del asesinato de los sindicalistas de la USO. Para empezar, el ataque contra los sindicalistas está inscrito dentro de una política más amplia del Estado colombiano y de las clases dominantes -en muchos casos en alianza con empresas transnacionales-, con la finalidad de facilitar la acumulación de capital y el aumento de ganancias, mediante la destrucción de las organizaciones sociales de los trabajadores o como forma de posibilitar la privatización de empresas y su entrega a compañías extranjeras. Examinando el panorama general del país en los últimos 20 años, se aprecia como regiones enteras fueron, literalmente hablando, limpiadas de sindicatos y sindicalistas, como en el Urabá antioqueño, para establecer unas nuevas condiciones, de terror paramilitar, en las cuales fuera prácticamente imposible la organización de sindicatos independientes.

La situación de los trabajadores petroleros está inscrita en esta misma lógica que apunta a criminalizar la protesta social y a impedir la organización sindical. Vale recordar que en un informe de inteligencia militar de la década de 1990 se afirmaba en contra de quien fuera presidente de la organización sindical lo siguiente:

"La USO es por esencia el brazo político militar de las organizaciones terroristas que delinquen en nuestro territorio, vemos como CESAR JULIO CARRILLO AMAYA es el máximo exponente y líder de esa agremiación aparentemente sindical, tal como se menciona en el informe de fecha 09 de agosto de 1996... De este sujeto se sabe que fue uno de los tantos promotores de la actividad terrorista emprendida contra el oleoducto caño Limón Coveñas. Tal actividad le representa o representaba al sindicato un mecanismo de presión sobre las Directivas de la Estatal petrolera en épocas de negociación de Convención Colectiva de Trabajo" ${ }^{\prime 51}$.

Este tipo de señalamientos denota, de una parte, el carácter anticomunista del ejército colombiano, heredado de la seguridad nacional en tiempos de Guerra Fría, el cual no puede concebir la existencia de sindicatos independientes, sino que los ubica como parte de grupos subversivos o terroristas. De otra parte, se evidencia que en esa lógica la sola pertenencia a 
cierto tipo de sindicatos ya es considerado como un delito. Al respecto vale la pena mencionar que un juez de Bogotá después de estudiar juiciosamente la situación de Pedro Chaparro concluyó que "se le acusó de ser líder sindical de la USO, postura criticable al resultar tentativo del derecho a la libre expresión, y comportaría criminalización de las formas legítimas de protesta" $^{\prime 52}$ (Gearoid O; 2007).

La arremetida paramilitar contra la USO está regida por la misma mirada antisindical y de criminalización gremial que ha llevado a que en los últimos 20 años hayan sido atacados no solamente las grandes organizaciones de trabajadores, sino también sindicatos más pequeños (de chóferes, por ejemplo). Esta estrategia buscaba generar terror entre los trabajadores organizados, golpeando primero a los sectores más débiles con menor capacidad de respuesta y denuncia, preparando el terreno para atacar la USO.

El objetivo final es la privatización plena de Ecopetrol para que todas las actividades de la explotación petrolera queden en manos de empresas cuya lógica es la del lucro, y el principal obstáculo para que eso sea posible, y lo que lo ha retardado ha sido la existencia de la USO. Esto se evidencia en el testimonio de un trabajador de Sabana de Torres, zona fuertemente golpeada por el paramilitarismo:

"Allí ha dado una alianza entre paramilitares y Ecopetrol. Dos ingenieros de la empresa están implicados en los sobornos que cometen los paramilitares. Les exigen el $5 \%$ a los contratistas de la empresa, para financiar su organización. El que no acepta las condiciones es tachado de colaborador de la guerrilla. Alexander Cardona miembro de la USO en Sabana de Torres fue descuartizado y decapitado por hacer estas denuncias. Es que a Sabana de Torres ha llegado Ramón Isaza, líder paramilitar que desplazó a Camilo Morantes que ahora tiene una orden de captura. Aquí en Barranca existe la amenaza a través de un panfleto de que es inminente una incursión paramilitar y que habrá una ofensiva contra los directivos de la USO"153.

Uno de los objetivos de la violencia paramilitar ejercida contra los trabajadores petroleros ha sido controlar la adjudicación de los contratos en Ecopetrol, en la medida en que esta forma de vinculación laboral se ha ido generalizando. La USO ha sido un obstáculo para el control paramilitar de dichos servicios, lo cual le ha acarreado la persecución estatal y paramilitar ${ }^{54}$. Al respecto es interesante mencionar-por la celebridad que ha cobrado ese personaje por aquello del cohecho de la reelección de Uribe- el siguiente caso:

"Una de las entidades que más contratos maneja es la Cooperativa de Trabajo Asociado para el Desarrollo Social y Comunitario (Integrar) que tiene siete de los 27 contratos del programa Empleo en Acción del Plan Colombia en Barrancabermeja. Trabajadores de esa entidad figuran entre las 460 personas secuestradas. La institución es dirigida por Yiris (sic) Medina, quien 
ocupó el segundo renglón en la lista electoral de Iván Díaz Mateus (lista que apoyaba a Álvaro Uribe Vélez). La Contraloría General de la Nación "investiga si Medina se benefició del proyecto y de los recursos para su campaña (...) entre noviembre del año pasado (2001) y marzo del presente (2002) esa cooperativa manejo recursos del Plan (Colombia) por 270 millones de pesos" ${ }^{\prime \prime 5}$.

La cuestión de los contratistas en Ecopetrol ha sido una preocupación de la USO por múltiples razones: esas empresas no reconocen al sindicato, sus sueldos son inferiores a los establecidos por ley, sus contratos son por servicios y no por tiempo, son efímeros y no fijos. Los contratos deterioran las condiciones laborales y debilitan al sindicato, en la medida en que el sistema de contratistas fue generando la privatización de Ecopetrol, uno de los objetivos prioritarios tanto del Estado colombiano como de las empresas petroleras extranjeras.

Todo lo que está asociado a la protesta que organizan los sindicatos independientes, marchas, movilizaciones, paros, se hace imposible, porque sencillamente eso aparece como propio de la subversión y los paramilitares no lo toleran. El impacto cultural y político de este cambio es brutal, como lo registra el testimonio adolorido de un trabajador de Puerto Wilches, cuyas palabras fácilmente pueden ser extrapoladas a las zonas petroleras:

"Todavía me da tristeza y a veces me da nostalgia cuando miro las convenciones colectivas y las comparo con las de antes, cuando en las marchas de los primeros de mayo se veía la alegría. Yo decía: las marchas de los primeros de mayo son un pretexto para encontrarme con mi compañero de trabajo y hablar de algo diferente. $Y$ hoy decir que las marchas de los primeros de mayo en Puerto Wilches son un pretexto para no salir a la calle para que no me vean, para que no me identifiquen, para que no me señalen" ${ }^{157}$.

Finalmente, para considerar rápidamente el asunto de la flexibilización laboral, lo que han sufrido los trabajadores petroleros es resultado de la confluencia de dos aspectos complementarios, uno de tipo político y otro de tipo económico: de un lado la imposición del neoliberalismo con todos sus procedimientos de eliminación de garantías sociales, derechos y conquistas de los trabajadores y, de otro lado, la estigmatización y criminalización de los sindicatos, como mecanismo encaminado a facilitar la implementación del neoliberalismo. En esta perspectiva, el paramilitarismo es una expresión del neoliberalismo, algo así como un neoliberalismo armado, que busca la aplicación brutal de la flexibilización con la eliminación física de los dirigentes sindicales y la implantación del terror como mecanismo de control social, en regiones donde por la tradición histórica de lucha y resistencia, entre ellas la de la insurgencia armada, ha sido mucho más difícil y demorada la implementación plena del neoliberalismo. Como bien se dice en una investigación sobre el impacto del paramilitarismo en Barrancabermeja: "El dominio paramilitar, como estrategia y modelo brutal de represión contra 
la población civil, estaba en marcha, como avanzada del modelo político-económico que el Estado planificaba para la región, destinado a modificar las relaciones capital-trabajo, para estructurar un nuevo orden de seguridad neoliberal".

\subsection{Acciones de la USO en defensa de la vida en la década de 1990}

A pesar de la persecución y el asesinato durante la década de 1990, las protestas de la USO no desaparecieron sino que antes por el contrario se intensificaron, teniendo como principal característica la lucha por el derecho a la vida.

En la región del Magdalena Medio durante toda la década adquieren connotación las movilizaciones de tipo político de los trabajadores asalariados, como resultado obvio del incremento de la violencia contra ellos mismos y sus sindicatos. De un total de 123 paros y huelgas que se presentaron entre 1990 y 2001 en la región, solamente 24 (un 19.5 por ciento) se originaron en pliegos de peticiones, mientras que 69 (56.1 por ciento) correspondieron a protestas políticas. Casi el 90 por ciento de los huelguistas que se movilizaron en ese período lo hicieron por razones políticas, solidaridad o por violaciones a las condiciones de trabajo. En el Magdalena Medio, más que en cualquier otra región del país, las luchas adquirieron un carácter prácticamente ilegal, si se miran desde el ángulo formal del Código Sustantivo del Trabajo vigente.

Más específicamente, esas huelgas de carácter político tenían como motivaciones principales protestar contra los atentados, asesinatos, amenazas y agresiones de que fueron víctimas los trabajadores de la región, todo lo cual originó el 87 por ciento del total de movilizaciones labores de tipo político. En todos los años de la década señalada se organizaron paros para protestar por asesinatos o desapariciones de líderes obreros o populares, para completar un total de 60 paros, presentándose en 1990 la mayor cantidad, 14, seguido de 8 en 1993 y de 5 en $1998^{58}$ (Delgado Alvaro; 2006 ).

Estas movilizaciones eran principalmente reactivas y defensivas, puesto que se presentaban inmediatamente después del crimen de un dirigente sindical de la USO o de un líder político de talla nacional (como sucedió cuando asesinaron a tres candidatos presidenciales de izquierda, entre 1987 y 1990). Después del asesinato de Chacón, en enero de 1988, la USO decidió realizar un paro cada vez que uno de sus miembros sufriera un atentado. Esta determinación era correcta y perfectamente legítima, porque suponía movilizarse en defensa de la vida, lo cual entre otras cosas le daría mucho más sentido a la lucha gremial. El inconveniente estaba en que, dada la criminalidad reinante en el Magdalena Medio y en Barrancabermeja, en particular, a diario eran asesinados líderes populares, defensores de derechos humanos, campesinos y 
colonos refugiados en el puerto, y la USO no podía llamar a paralizar la producción, salvo en casos excepcionales. Ante esto, mucha gente del puerto consideraba que la actitud del sindicato no era del todo solidaria, ya que convocaba a paro cuando la atacaban directamente, pero no hacía lo mismo cuando los afectados pertenecían a otros sectores sociales.

Aunque miembros de la USO apoyaban y participaban en esas acciones, en muchos casos lo hacían más a título individual, porque daba la impresión de que la organización sindical se ocupaba mucho más de sus propios asuntos que los de la gente del municipio en general. Como lo reconoció Cesar Carrillo "hubo momentos en los que mataban a un líder por mes. Y claro, organizar cada mes un paro de producción en ECOPETROL comenzó a ponerse difícil, parábamos por pedazos porque la empresa también comenzó a tomar unas medidas que nos impedían coordinar las actividades que afectaban a la producción. Era más factible organizar una actividad de protesta y eso no afectaba a la producción ${ }^{\prime \prime 59}$.

Aunque se hubiera dado un paso adelante en el tipo de lucha laboral que se adelantaba, que desbordaba el marco exclusivamente reivindicativo, paradóficamente dada la frecuencia que alcanzó -como resultado de los ataques contra el sindicato- fue distanciando aún más a la USO de la población. También aumentó el control y la represión por parte de Ecopetrol, que aprovechó la situación para implementar sus planes de contingencia, cuando empezó a sustituir a trabajadores de base por directivos, reafirmando una tendencia de reestructuración laboral que se venía dando desde comienzos de la década de 1980, consistente en ocupar una mayor cantidad de personal administrativo en relación con los trabajadores ligados a actividades productivas. Unos pocos datos son indicativos de esta transformación. En 1981, Ecopetrol tenía 9971 trabajadores, de los cuales 2200 eran directivos y en 1999 tenía 10381 empleados, de los cuales sólo el 60 por ciento estaba dedicado a labores productivas que territorialmente estaban distribuidos así: "471 1 en Santander, 527 en Norte de Santander, 380 en Antioquia, 149 en Huila, 142 en Boyacá, 113 en Putumayo, 96 en Tolima, 94 en Meta, 12 en Casanare y apenas 6 en Arauca" $^{160}$ (Delgado Alvaro; 2006).

En otros términos, Ecopetrol logró independizarse hasta cierto punto de los trabajadores directos mediante dos estrategias típicas del capitalismo: el desarrollo tecnológico y la sustitución de trabajadores por directivos o por personal con similar capacitación a los obreros calificados, pero no sindicalizados que cumplían labores de esquirolaje permanente en épocas de paro, así los paros duraran 24 horas.

Al mismo tiempo, en una dialéctica perversa el círculo de la violencia conspiraba contra la USO en todos los sentidos. El sindicato soportaba un atentando o un asesinato, causado por fuerzas estatales y paramilitares, lo que lo llevaba a organizar paros y protestas, y estas formas de lucha eran vistas por los sicarios, abiertos o encubiertos, como una demostración de que los petroleros 
no querían trabajar y que eran enemigos de la prosperidad y del progreso, y, en consecuencia, los volvían a atacar para que se disciplinaran y acataran los principios del orden paramilitar en ciernes, que se había aplicado en otras zonas del Magdalena Medio. Esta labor de persecución y señalamiento se facilitaba, porque desde dentro de la misma empresa -en sus propias instalaciones- operaban y se movían a sus anchas reductos paramilitares. Con ello se aterrorizaba a los trabajadores y a toda la población, para acallarlos y desmovilizarlos y conseguir la implantación de la flexibilización laboral de Ecopetrol y preparar el terreno para su privatización y la entrada de las empresas multinacionales.

\section{Conclusiones}

La política antisindical librada contra la USO en el último cuarto de siglo se mantiene hasta el día de hoy, como se verifica con las amenazas que siguen recibiendo los sindicalistas y dirigentes populares de Barrancabermeja. A mediados de 2008 seis organizaciones sociales, entre ellas varios sindicatos recibieron intimidaciones de las llamadas Águilas Negras. Este grupo emergente de paramilitares dirigió un comunicado, con membrete en donde los acusa de ser auxiliadores de la guerrilla a la Asociación de Directivos Profesionales y Técnicos de Empresas de la Industria del Petróleo de Colombia (ADECO) y a la Unión Sindical Obrera (USO).

Las Águilas Negras justifican la amenaza diciendo que "una vez más nos estamos llenando de guerrilleros rasos, que escondidos bajo sucios y burdos engaños a los pobladores, quieren tomar el control de la ciudad para volver a los viejos tiempos en los cuales sólo había extorsiones, asesinatos, sindicalistas y ONG a su servicio, para colmar sus fines revolucionarios y con ésto buscar la desestabilización del Estado". Agregan que "nuestra organización no está dispuesta a permitir la entrada de estos guerrilleros ni de sus auxiliadores, que se han atrevido a poner pie nuevamente en nuestra Barrancabermeja". Y señalan que las organizaciones en mención "están llenas de sindicalistas revolucionarios y auxiliadores de la guerrilla, están promoviendo y financiando el nacimiento (sic) y accionar de estos grupos insurgentes, por esta razón son declarados enemigos nuestros y objetivo militar por parte de nuestra organización ${ }^{\prime \prime 61}$.

Como es obvio, las amenazas, atentados, asesinatos, torturas y desapariciones a que han sido sometidos los dirigentes sindicales de la USO han tenido consecuencias negativas sobre el mismo funcionamiento del sindicato y sus posibilidades de desarrollo y de vínculos con la población.

Una primera consecuencia, la destrucción de las organizaciones sociales que ha corrido a cargo del Estado y de los grupos para estatales de pájaros y sicarios amplió el aislamiento de la USO del resto de la población, lo cual coincidió con el cambio en el ritmo de la protesta social, a fines 
de la década de 1980, cuando se redujeron drásticamente, hasta casi desaparecer, las protestas y movimientos cívicos.

No estamos diciendo que los vínculos con la población se hayan roto solamente por la violencia y los asesinatos, sino que las acciones criminales acentuaron un proceso de separación entre los trabajadores de la USO y el resto de la población que ya estaba en camino. Esta separación se originó cuando, por el crecimiento de Barrancabermeja y la consolidación de algunas conquistas laborales de los trabajadores petroleros, afiliados a la USO, éstos se concentraron en disfrutar de esas conquistas (en materia de salud, educación, régimen de jubilación) y se desligaron del resto de la población, viviendo en barrios de clase media (que cuentan con todos los servicios) y marchándose de la ciudad durante los períodos de descanso y definitivamente luego de pensionados. Esto hizo que se presentara un divorcio entre la USO y la población pobre del puerto (la mayoría abrumadora), la cual dejó de ser involucrada en las reivindicaciones del sindicato, que históricamente había jugado un rol central en la escasa redistribución por parte de ECOPETROL de las espectaculares ganancias que obtiene por la explotación del petróleo. El sindicato y sus afiliados se concentraron en sus reivindicaciones económicas y en sus contradicciones con la empresa, pero se mostraron apáticos con respecto a los barrios y las comunidades. Por ello, el apoyo a la USO en los barrios había disminuido ya a mediados de la década de 1990 e importantes sectores del comercio fueron reclutados por los paramilitares. Como lo dijo gráficamente una investigadora: "Antes los sindicalistas les metían plata y trabajo a los barrios, a la educación pública, etc. Hoy sólo los suicidas van a los barrios. Los paramilitares les dan el consejo de que se limiten a pelear por sus reivindicaciones laborales y no se metan con los barrios" ${ }^{\prime \prime 2}$ ( Cadavid Amparo; 1996)

Ante la generalización de ataques contra miembros de la USO, el sindicato debió encerrarse y resguardarse, con lo cual aumentó su distanciamiento de la población pobre del Municipio de Barrancabermeja, pero igual cosa ha sucedido en todos los lugares donde tiene sedes la USO. Los dirigentes sindicales deben movilizarse en vehículos polarizados y rodearse de escoltas, con lo cual se rompen los posibles nexos con la población, ya que resulta muy complicado acercarse y hablar con alguien que debe tomar muchas medidas de seguridad. Eso mismo se fue convirtiendo en caldo de cultivo para el burocratismo, generando ciertos privilegios materiales de los que no disfrutan todos los trabajadores petroleros, como son los de acceder a un esquema de seguridad con escoltas y carro blindado.

Desde muy temprano Manuel Gustavo Chacón comprendió el impacto nefasto que tenían los atentados sobre las posibilidades de movimiento libre de los sindicalistas de la USO. Por sU carácter desprendido, solidario y festivo, encontraba muy incómodo para su accionar normal de andariego, estar sujeto a la disciplina y control estricto que supone desplazarse en automóvil e ir armado para defenderse. Chacón pensaba que esto lo limitaba tremendamente y por eso rehuía 
este tipo de restricciones, aunque finalmente debió, por fuerza de las circunstancias, aceptar el porte de armas y la utilización del carro blindado.

Una segunda consecuencia está relacionada con la flexibilización laboral que hemos mencionado en otros lugares de este capítulo. La violencia directa ha permitido la flexibilización terrorista de las labores de los obreros petroleros, con la eliminación del trabajo fijo y la imposición de las cooperativas y el trabajo temporal, en muchos casos directamente controlado por sectores paramilitares. Por supuesto, que eso ha debilitado al sindicato porque las posibilidades de enfrentar el fenómeno paramilitar, armado y apoyado por el Estado, son bastante difíciles, máxime cuando los paramilitares y sus voceros están en los propios campos petroleros $o$ en los barrios nororientales de Barrancabermeja, donde viven algunos trabajadores. En estas condiciones, la labor gremial, de agitación, propaganda y organización se torna muy complicada, es casi un acto heróico. Como lo indica un antiguo dirigente petrolero:

"En los lugares de explotación o actividad petrolera donde la USO tiene presencia sindical, hay una situación muy difícil para el sindicato. Trabajadores de base nos dijeron que el sindicato se estaba quedando en minoría a causa del problema de los trabajadores temporales y de las empresas subcontratadas. Por un lado, se extiende la precariedad laboral y disminuye la sindicalización en ECOPETROL. Por otro lado, denunciaron que a través de las empresas subcontratistas se están infiltrando paramilitares como pasa con las empresas de seguridad privadas o de limpieza. Las bases de la USO sentían que se encontraban en minoría. Hasta situaciones dramáticas, como por ejemplo en El Centro... donde los trabajadores, ni siquiera los afiliados de la USO querían hablar, y si hablaban no decían el nombre. En otro sitio, los paramilitares habían visitado a los dirigentes sindicales dentro de las instalaciones de ECOPETROL. ¿̇El sindicato es capaz de enfrentar una situación, teniendo un enemigo armado, ilegal, en ofensiva contra él en los sitios en donde opera?" ${ }^{163}$.

Esta es la misma situación que impera en la mayor parte de las zonas petroleras, en Barrancabermeja, en Tibú, en Sabana de Torres, en Yondó, en Cantagallo... y su rutinaria repetición simplemente indica que tras el petróleo colombiano existe una estrategia de control, que cuenta entre sus dispositivos centrales con la desorganización de los trabajadores para propiciar una apropiación más fácil y directa de los recursos energéticos. Por supuesto, esto hace mucho más complicado el intento de organización sindical, lo cual ha incidido negativamente en la USO, en los últimos tiempos. 


\section{Referencias bibliográficas:}

'VEGA Cantor, Renan, Núñez Luz Angela y Pereira Alexander. Petróleo y protesta obrera. La USO y los trabajadores petroleros en Colombia (1923-2008), 2 volúmenes, Corporación Aury Sara (2009).

2.Gloria Lucy Zamora (1983), En el Magdalena Medio. Los moradores de la represión, CINEP, Bogotá, pp. 37-39.

3.Carlos Medina Gallego y Mireya Tellez Ardila,(1994), La violencia parainstitucional, paramilitary parapolicial en Colombia, Rodríguez Quito Editores, Bogotá, pp. 88-89.

${ }^{4}$.Carlos Medina Gallego,(1990) Autodefensas, paramilitares y narcotráfico en Colombia, Documentos Periodísticos, Bogotá, pp. 219 y ss.

5."La pesadilla paramilitar", Cambio, No. 173, octubre 7 de 1996, p. 13.

6. Mauricio Romero,(2003), Paramilitarismo y autodefensas, 1982 - 2003, Editorial Planeta, Bogotá, pp. 26-27.

7. CREDHOS y CINEP, Barrancabermeja, la otra versión,... op. cit., pp. 96-97.

8. "12 grupos paramilitares y parapoliciales en el país", en Solidaridad, No, 48, septiembre de 1983, pp. $7-8$.

9. La Prensa, mayo 14 de 1989.

${ }^{10}$. Entrevista a Javier Giraldo, en Barrancabermeja, la otra versión...op. cit, p. 94.

". Esta caracterización es tomada de Libardo Sarmiento Anzola, "El Magdalena Medio: un modelo piloto de modernización autoritaria en Colombia", en Utopías, No. 39, octubre de 1996, pp. 13.

12. Ibíd., p. 15.

13. Michael T. Klare, (2003), Guerras por los recursos. El futuro escenario del conflicto global, Ediciones Urano, Barcelona,

14. Gearóid O. Loingsigh, (2007), Catatumbo un reto por la verdad, Comité de Integración Social del Catatumbo - Corporación Sembrar, Bogotá, pp. 14-15. 
15. Colombia Nunca Más, (2008), Crímenes de lesa humanidad en la Zona Quinta, Corporación Colectivo de Abogados José Alvear Restrepo, Bogotá, p. 31 .

${ }^{16}$. G. Piccoti, op. cit., p. 159.

17. Ibíd., p. 179.

${ }^{18}$. Colombia Nunca Más. Crímenes de lesa humanidad en la Zona Quinta, pp. 34-35.

19. Gearóid O. Loingsigh, Catatumbo un reto por la verdad, p. 233.

${ }^{20}$. Ibíd., p. 236.

${ }^{21}$. Colombia Nunca Más. Crímenes de lesa humanidad en la Zona Quinta, . 35.

${ }^{22}$. Ibíd., pp. 35-36.

${ }^{23}$. Vanguardia Liberal, febrero 12 de 2002.

${ }^{24}$. Citado en G. Piccoti, op. cit., pp. 126 y 159.

25. Guillermo Correa Montoya, 2515 o esa siniestra facilidad para olvidar. 21 años de asesinatos de sindicalistas en Colombia, Cuaderno de Derechos Humanos No. 19, Escuela Nacional Sindical, Medellín, julio de 2007, p. 81.

${ }^{26}$. El Tiempo, mayo 1 del 2005.

27. Colombia Nunca Más. Crímenes de lesa humanidad en la Zona Quinta, p. 292.

${ }^{28}$. Ibíd., p. 287.

29. Ibíd., pp. 293-294.

30. "El hombre que se negaba a matar mariposas... pero fue acusado de homicidio y terrorismo, Entrevista con César Carrillo, ex presidente de la USO. Hoy exiliado en España", en V. Carrillo y T. Kucharz, op. cit., pp. 303-304.

31. "Barranca otra vez". en Colombia Hoy Informa, No. 54, 1988, p. 31.

32. Colombia Nunca Más. Crímenes de lesa humanidad en la Zona Quinta, p. 295. 
33. Ibíd., pp. 287-288

${ }^{34}$. Para la redacción de este apartado nos hemos basado en: "Primera confesión", "Segunda confesión", en La Prensa, enero 4 de 1994, pp. 13-16; Corporación Colectivo de Abogados José Alvear Restrepo - Corporación Regional para la Defensa de los Derechos Humanos, CREDHOS, Hoy, como ayer, persistiendo por la vida. Redes de Inteligencia y exterminio en Barrancabermeja, Bogotá, 1999, p. 33; Red de asesinos en Colombia; Colombia, nunca más, zona quinta..., op. cit.

${ }^{35}$. Human Rights Watch, "Las redes de asesinos, op. cit., p. 139.

${ }^{36}$. Ibíd., p. 140

${ }^{37}$. Ibíd., p. 141

${ }^{38}$. Citado en Hoy, como ayer, ..., op. cit., pp. 85-86. (Énfasis nuestro).

39. Fiscalía General, Indagatoria de Carlos Alberto Vergara Amaya, Cuaderno 12, folio 217 y ss. del expediente, citado en Hoy como ayer, ... p. 110.

${ }^{40}$. Hoy, como ayer, ..., op. cit.

${ }^{41}$. Ibíd.

42. "DINTE Red-007: ¿Con licencia para matar?, en Alternativa, No. 20, diciembre 1998-enero de 1999, p. 14.

43. "Primera confesión", La Prensa, enero 4 de 1994, p. 14.

${ }^{44}$. Citado en Hoy, como ayer, ...p. 151.

${ }^{45}$. Eduardo Umaña Mendoza, "A los trabajadores del mundo! Represión a los trabajadores de la USO. La justicia sin rostro... Sin rostro de justicia", publicado en Camilo Eduardo Umaña Hernández, Las altisonancias del silencio. Más vale morir por algo que vivir por nada, s. e., Bogotá, 2008, p. 77.

46. Citado en C. E. Umaña Hernández, op. cit. p. 72

${ }^{47}$. Eduardo Umaña Mendoza, "A los trabajadores del mundo", op. cit., p. 78. 
${ }^{48}$. lbíd., p. 78.

${ }^{49}$. Ibíd., pp. 83-84.

50. Eduardo Umaña Mendoza, "Documento de denuncia sobre amenazas", publicado en C. E. Umaña Hernández, op. cit., pp. 93-94..

${ }^{51}$. Citado en G. O. Loingsigh, La estrategia integral..., op. cit., p. 40.

${ }^{52}$. Citado en G. O. Loingsigh, La estrategia integral..., op. cit, p. 39.

53. "USO nace en Barranca", en Alternativa, No. 20, diciembre 1998-enero 1999, p. 22.

${ }^{54}$. Colombia Nunca Más..., op. cit., p. 34.

${ }^{55}$. G. O. Loingsigh, Estrategia integral, p. 23.

56. Magda Beatriz López, (2005),“Puerto Wilches: sindicatos y actores políticos armados, 1996 2002", en Controversia, No. 185, diciembre de, pp. 125-126.

${ }^{57}$. Barrancabermeja, la otra versión, p. 97.

58. Álvaro Delgado, (2006), "El conflicto laboral en el Magdalena Medio", en Mauricio Archila et al., Conflictos, poderes e identidades en el Magdalena Medio, 1990-2001, CINEP, Bogotá, pp. 100-104.

59. "El hombre que se negaba a matar mariposas...", op. cit., p. 306.

${ }^{60}$. A. Delgado, op. cit., pp. 131-132.

61. "Águilas Negras amenazan a dirigentes sociales en Barrancabermeja", Semana. com, julio 23 de 2008

62. Amparo Cadavid, El Magdalena Medio una región que se construye por el río. Diagnóstico propositito, Programa de Desarrollo y Paz del Magdalena Medio, 1996, citado en A. Delgado, op., cit., p. 133.

63. "La USO es un sindicato que históricamente ha sido una piedra en el zapato...", op. cit., p. 322. 